Article

\title{
Biofuel and Biochemical Analysis of Amphora coffeaeformis RR03, a Novel Marine Diatom, Cultivated in an Open Raceway Pond
}

\author{
Muthu Ganesan Rajaram 1,2, Subramani Nagaraj 1,2 (1), Manubolu Manjunath ${ }^{3}$, \\ Annakkili Baskara Boopathy ${ }^{1,4}$, Chidambaram Kurinjimalar ${ }^{1}$, Ramasamy Rengasamy ${ }^{1}$, \\ Thanasekaran Jayakumar ${ }^{2}$, Joen-Rong Sheu ${ }^{2, *}$ and Jiun-Yi $\mathrm{Li}^{2,5, *}$ \\ 1 Centre for Advanced Studies in Botany, University of Madras, Guindy Campus, Chennai 600025, \\ Tamil Nadu, India; raja.ram091@gmail.com (M.G.R.); nagalilly@gmail.com (S.N.); \\ annakkilibaskar@gmail.com (A.B.B.); cskurinjimalar@gmail.com (C.K.); profrrengasamy@yahoo.com (R.R.) \\ 2 Department of Pharmacology, Graduate Institute of Medical Sciences, College of Medicine, Taipei Medical \\ University, Taipei 110, Taiwan; tjaya_2002@yahoo.co.in \\ 3 Department of Evolution, Ecology and Organismal Biology, Ohio State University, Columbus, OH 43210, \\ USA; manubolu.1@osu.edu \\ 4 Department of Biochemistry, Caussanel College of Arts and Science, Ramanathapuram 623523, India \\ 5 Department of Cardiovascular Surgery, Mackay Memorial Hospital, and Mackay Medical College, \\ Taipei 104, Taiwan \\ * Correspondence: sheujr@tmu.edu.tw (J.-R.S.); JYL5891@ms2.mmh.org.tw (J.-Y.L.); \\ Tel.: +886-2-2736-1661 (ext. 3199) (J.-R.S.); Fax: +886-2-2739-0450 (J.-R.S.)
}

Received: 29 March 2018; Accepted: 22 May 2018; Published: 25 May 2018

\begin{abstract}
Background: To increase the biochemical productivity and to reduce the production cost of microalgal biodiesel, this study aimed to investigate the effects of $\mathrm{CO}_{2}$ on biomass, fatty acids, carbon-hydrogen, and biochemical accumulation of the marine diatom, Amphora coffeaeformis RR03 (A. coffeaeformis) RR03. (2) Methods: Fatty acid composition of the dry biomass of A. coffeaeformis RR03 was analysed using Gas chromatography-mass spectrometry (GC-MS). (3) Results: The results showed that $A$. coffeaeformis RR03 contained high biomass productivity and biochemical composition in different cultivation conditions. A. coffeaeformis RR03 showed maximum growth of $5.2 \times 10^{6} / \mathrm{mL}$ on 21st day cultivation under $\mathrm{CO}_{2}$ supply. The bio-crude oil production from A. coffeaeformis RR03 was 36.19 megajoule (MJ). GC-MS analysis found that the dry biomass of $A$. coffeaeformis RR03 contained maximum of $47.72 \%$ fatty acids of 16-octadecanoic acid methyl ester (10:12) and $19.58 \%$ pentadecanoic acid, 13-methyl-, and methyl ester (9.24). (4) Conclusion: The results of this study may suggest that a novel diatom of $A$. coffeaeformis RR03 could be a suitable candidate for biocrude production in order to meet the future demand of energy.
\end{abstract}

Keywords: biomass; lipids; biocrude; bioenergy; A. coffeaeformis RR03

\section{Introduction}

Marine diatoms, which are the most important eukaryotic phytoplankton for carbon sequestration and the main producers within phytoplankton today, contribute more than $40 \%$ of the global oceanic organic carbon production per year and are responsible for up to $25 \%$ of the global $\mathrm{CO}_{2}$ fixation [1]. Diatoms produce oil drops that are as a reserve material during the vegetative period of growth, with percentages that vary from $23 \%$ to $45 \%$ of dry cell weight. Physiological and genetic manipulations have also shown the possibility of increasing the amount of lipids in the cellular mass and re-invigorated studies regarding the potential of affording oil production using these 
microorganisms [2]. In addition, marine strains showed more resistance to environmental changes in cultivation, as they are adapted to survive in high levels of salinity. For this reason, and due to the large seawater availability, which can be used in microalgae culture, it is expected that these microorganisms may supply the growing biofuel demand, shifting it from petroleum, natural gas, and coal derived fuels to biofuels produced from marine microalgae [3].

In recent years, public awareness has been raised to reduce $\mathrm{CO}_{2}$ emissions around the world. Of the various physical, chemical, and biological methods that can be used to capture $\mathrm{CO}_{2}$, the $\mathrm{CO}_{2}$ biological fixation using microalgae is thought to be one of the most important and effective approaches and is considered as a renewable, energy-saving, and sustainable technology for the reduction of $\mathrm{CO}_{2}$ emissions [4]. A diverse potential of various algal species has been analysed in terms of ecological, economical, and bioenergy production [5]. The biochemical components of algae like protein, carbohydrates, and lipids have been used in different industries of food, cosmetics, and medicines. The dynamics of microalgae growth, as well as inorganic carbon and nutrients uptake, were extensively studied during the pond start-up and semi-continuous feeding conditions [5].

Several strains of microalgae were recently found to be highly tolerant to $\mathrm{CO}_{2}$, because they can grow under high $\mathrm{CO}_{2}$ concentrations (mostly $1-15 \%$ ) and simultaneously produce a significant amount of lipids for biodiesel production [4]. Microalgae need simple requirements (light, water, $\mathrm{CO}_{2}$, and minerals) for growth and photosynthesis. They can produce promptly large amounts of lipids, proteins, and carbohydrates [6]. These microorganisms accumulate triglycerides as a storage lipid under specific culture conditions. Microalgal lipids are the green oil for sustainable biodiesel production [7]. The increase of growth rate and the improvement of lipid content of microalgal strain have the one challenge to fully exploit this potential [8]. Cyanophyceae, Chlorophyceae, Bacillariophyceae, and Chrysophyceae are the most abundant sources of microalgae biodiesel production [9].

Currently, crops are the common feed stocks in the biodiesel production industry, as well as the food industry; thus, crop-based biofuels production has created increased food prices [10]. A wide variety of microalgae species reach higher lipid productivities than crops, hence becoming potential substrates to alleviate the referred-to "food-versus fuel competition" [9]. Despite the efforts that have been taken, industrial biodiesel production from microalgae is not economically viable nowadays due to the high costs of drying and lipid extraction processes [11]. In the present study, diatom of Amphora coffeaeformis RR03 (A. coffeaeformis) were mass cultivated in $150 \mathrm{~L}$ and $1500 \mathrm{~L}$ outdoor open raceway ponds. Two distinct types of open bioreactors were used to determine the production of high oil content. The possible contaminating factors were also examined using a non-sterile medium. These results provided new insights to the mass cultivation of new A. coffeaeformis RR03 towards efficient biocrude and biodiesel production.

\section{Results}

\subsection{Mass Cultivation of A. coffeaeformis RR03}

The dry biomass of about $0.05 \mathrm{~g}$ on the initial day was gradually increased up to $0.56 \mathrm{~g} \mathrm{~L}^{-1}$ on 6th day. Thereafter, the dry biomass was increased to a maximum of $0.81 \mathrm{~g} \mathrm{~L}^{-1}$ on 15 th day. The alga exhibited maximum cell number of $2.5 \times 10^{6}$ cells $/ \mathrm{mL}$ on 15 th day when it was grown in the modified Central Food Technological Research Institute- Rajaram A. coffeaeformis (CFTRI-RRAC I) medium as shown in Figure 1a,b. The alga grown in another pond in F/2 medium (control) inoculated with $0.05 \mathrm{~g} \mathrm{~L}^{-1}$ of dry biomass was gradually increased to a maximum of $0.79 \mathrm{~g} \mathrm{~L}^{-1}$ on 18th day, which was similar to the dry biomass recorded in the modified CFTRI-RRAC I medium on 15th day. A. coffeaeformis RR03 showed the biomass productivities of $0.054 \mathrm{~g}$, and $0.043 \mathrm{~g} \mathrm{~L}^{-1} \mathrm{~d}^{-1}$ in the modified CFTRI-RRAC I and F/2 medium, respectively. The volumetric and areal productivity of biomass were 0.031 and $0.029 \mathrm{~g} \mathrm{~L}^{-1} \mathrm{~d}^{-1}$ and 4.65 and $4.35 \mathrm{~g} \mathrm{~L}^{-1} \mathrm{~m}^{2} \mathrm{~d}^{-1}$, respectively. At the end of study 
period (21st day), $0.192 \mathrm{~kg}$ and $0.161 \mathrm{~kg}$ dry biomass were harvested from the alga grown in modified CFTRI-RRAC I medium and F/2 medium, respectively, as shown in Table 1.

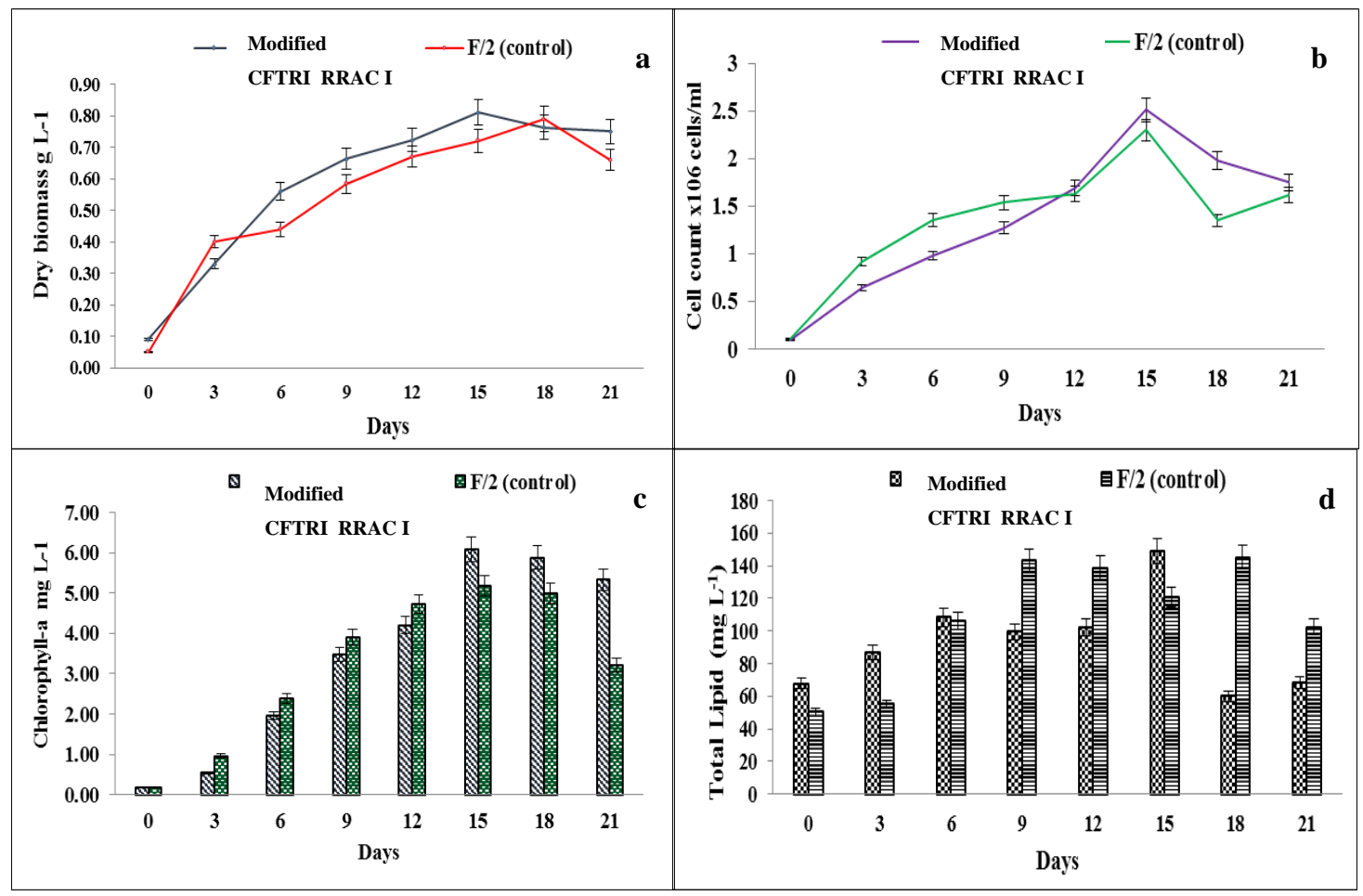

Figure 1. Amphora coffeaeformis RR03 cultivated in the modified CFTRI-RRAC I medium and F/2 control medium at different intervals in $1.0 \mathrm{~m}^{2}$ open raceway pond was subjected to the analysis of (a) dry biomass, (b) cell number, (c) chlorophyll-a, and (d) total lipid content.

Table 1. Biomass, lipids, volumetric, and areal productivity of A. coffeaeformis RR03 cultivated in $1.0 \mathrm{~m}^{2}$ and $10.0 \mathrm{~m}^{2}$ open raceway ponds.

\begin{tabular}{|c|c|c|c|c|c|c|c|}
\hline $\begin{array}{l}\text { A. coffeaeformis RR03 } \\
\text { Cultivation Conditions }\end{array}$ & $\begin{array}{l}\text { Biomass Productivity } \\
\qquad\left(\mathrm{g} \mathrm{L}^{-1} \mathrm{~d}^{-1}\right)\end{array}$ & $\begin{array}{l}\text { Lipid Productivity } \\
\qquad\left(\mathrm{mg} \mathrm{L}^{-1} \mathrm{~d}^{-1}\right)\end{array}$ & $\begin{array}{l}\text { Lipid (\%) Content in } \\
\text { Ash Free Biomass }\end{array}$ & $\begin{array}{l}\text { Biomass } \\
\left(\mathrm{g} \mathrm{L}^{-1}\right)\end{array}$ & $\begin{array}{l}\text { Vol. Productivity } \\
\qquad\left(\mathrm{g} \mathrm{L}^{-1} \mathrm{~d}^{-1}\right)\end{array}$ & $\begin{array}{c}\text { Areal } \\
\text { Productivity } \\
\left(\mathrm{g} \mathrm{L}^{-1} \mathrm{~m}^{2} \mathrm{~d}^{-1}\right)\end{array}$ & $\begin{array}{l}\text { Drybiomass } \\
\quad(\mathrm{Kg})\end{array}$ \\
\hline $\begin{array}{l}\text { Modified RRAC I } \\
\text { medium in } 1.0 \mathrm{~m}^{2} \text { pond }\end{array}$ & $0.054 \pm 0.01$ & $9.93 \pm 0.05$ & $23.83 \pm 3.36$ & $\begin{array}{c}0.81 \pm \\
0.03\end{array}$ & 0.031 & 4.65 & 0.192 \\
\hline $\begin{array}{l}\mathrm{F} / 2 \text { medium in } \\
1.0 \mathrm{~m}^{2} \text { pond }\end{array}$ & $0.043 \pm 0.03$ & $15.88 \pm 0.08$ & $21.35 \pm 2.44$ & $\begin{array}{c}0.79 \pm \\
0.01\end{array}$ & 0.029 & 4.35 & 0.161 \\
\hline $\begin{array}{l}\text { Modified RRAC I } \\
\text { medium in } 10.0 \mathrm{~m}^{2} \\
\text { pond with }\left(\mathrm{CO}_{2}\right)\end{array}$ & $0.071 \pm 0.01$ & $7.60 \pm 0.05$ & $36.16 \pm 2.54$ & $\begin{array}{c}1.5 \pm \\
0.10\end{array}$ & 0.065 & 9.75 & 2.250 \\
\hline
\end{tabular}

\subsection{Biochemical Parameter Study on $1.0 \mathrm{~m}^{2}$ in Open Pond}

The maximum concentrations of 5.18 and $6.09 \mathrm{mg} \mathrm{L}^{-1}$ chlorophyll- $a$ were grown in the modified CFTRI-RRAC I and F/2 medium, respectively, on 15th day (Figure 1c). A. coffeaeformis RR03 had maximum total lipid content of $149 \mathrm{mg} \mathrm{L}^{-1}$ with $2.51 \times 10^{6}$ cells $/ \mathrm{mL}$ on 15 th day, when it was grown in the modified CFTRI-RRAC I medium. At the above condition, it exhibited $18.39 \%$ of total lipid/dry biomass and $23.83 \%$ total lipid/ash free biomass. Further, this alga showed the total lipid and ash free biomass of $9.93 \pm 0.05 \mathrm{mg} \mathrm{L}^{-1} \mathrm{~d}^{-1}$ and $21.35 \%$, respectively. However, the alga grown in F/2 medium (control) showed maximum total lipid content of $145 \mathrm{mg} \mathrm{L}^{-1}$ with $1.98 \times 10^{6}$ cells $/ \mathrm{mL}$ on 18 th day, as shown in Figure 1d. The results of biomass and lipid production are given in Table 1. 


\subsection{Effect of $\mathrm{CO}_{2}$ Supplementation on A. coffeaeformis RR03}

\subsubsection{Biomass Production and Biochemical Study in $10.0 \mathrm{~m}^{2}$ Open Pond}

A. coffeaeformis RR03 grown under $\mathrm{CO}_{2}$ supplementation had maximum concentrations of biomass $\left(1.5 \pm 0.10 \mathrm{~g} \mathrm{~L}^{-1}\right)$ and Chlorophyll-a $\left(13.18 \mathrm{mg} \mathrm{L}^{-1}\right)$ on 21st day, as shown in Figure 2a,b. The lipid content of $A$. coffeaeformis $\mathrm{RR} 03$ grown under $\mathrm{CO}_{2}$ supplementation was $114 \mathrm{mg} \mathrm{L} \mathrm{L}^{-1}$, with $4.03 \times 10^{6}$ cells $/ \mathrm{mL}$ on 15 th day, as shown in Figure $2 \mathrm{~d}$. The total cell number and lipid content of the alga in ash-free biomass under with $\mathrm{CO}_{2}$ also increased (Figure 2c,d). Similar trend of lipid productivity of $7.60 \pm 0.05$ and $21.88 \pm 0.15 \mathrm{mg} \mathrm{L}^{-1} \mathrm{~d}^{-1}$ was noticed in the presence or absence of $\mathrm{CO}_{2}$, respectively (Table 1). In case of control medium, the alga had a maximum lipid accumulation of $197 \mathrm{mg} \mathrm{L}^{-1}$ with $1.49 \times 10^{6}$ cells $/ \mathrm{mL}$ on 9 th day.

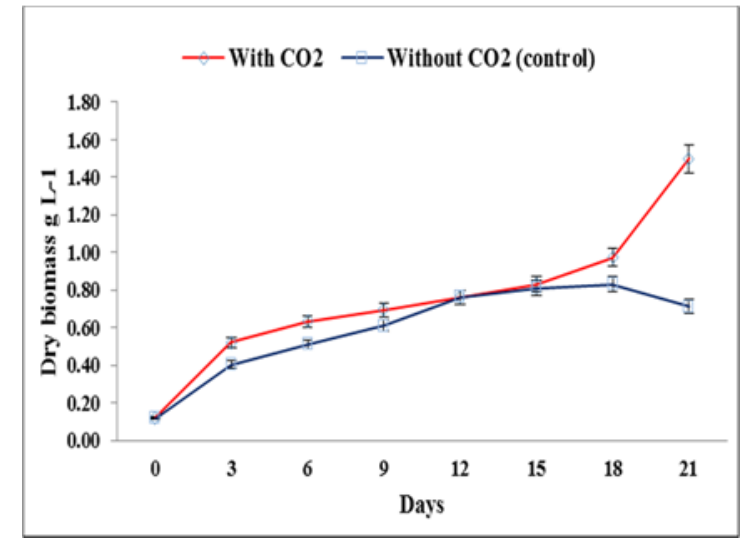

(a)

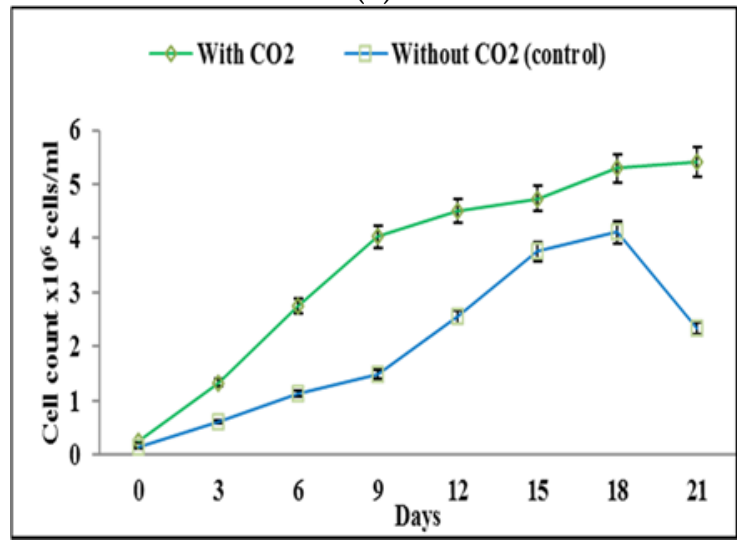

(c)

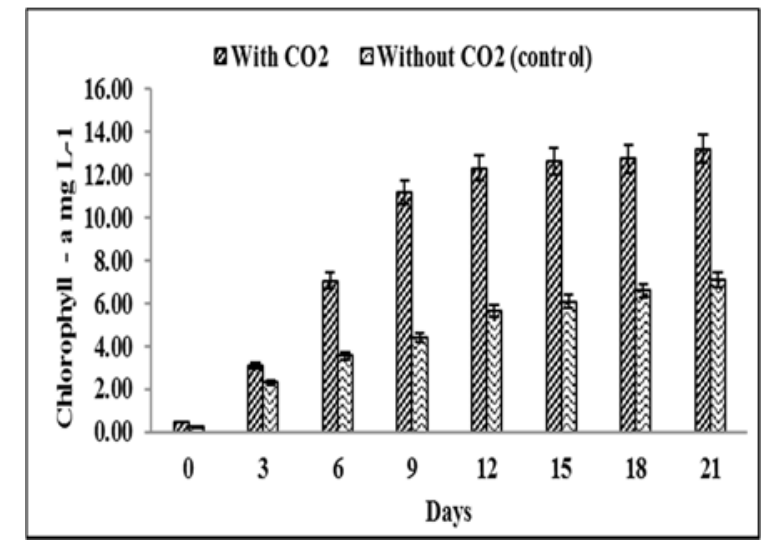

(b)

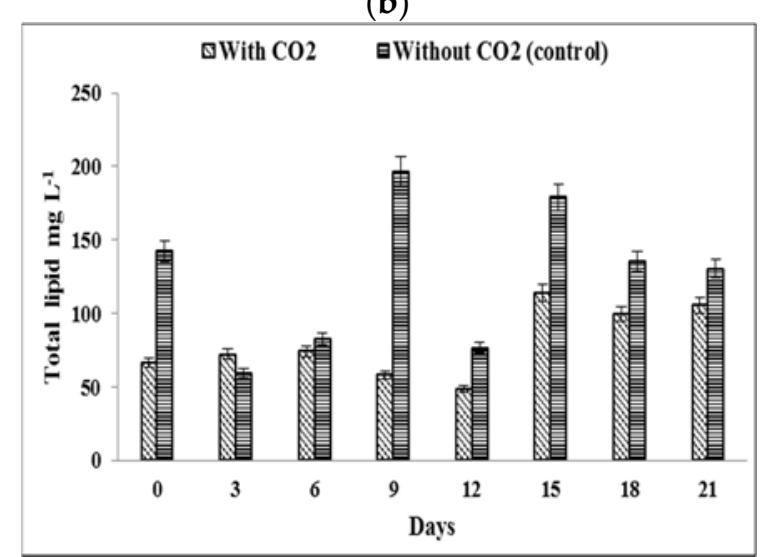

(d)

Figure 2. (a) Dry biomass of Amphora coffeaeformis $\mathrm{RR} 03$ with $\mathrm{CO}_{2}$ and without $\mathrm{CO}_{2}$-modified CFTRI-RRAC I medium at different intervals in $10.0 \mathrm{~m}^{2}$ open raceway pond. (b) Cell count of A. coffeaeformis RR03 with $\mathrm{CO}_{2}$ and without $\mathrm{CO}_{2}$-modified CFTRI-RRAC I medium at different intervals in $10.0 \mathrm{~m}^{2}$ open raceway pond. (c) Chlorophyll-a content of $A$. coffeaeformis $\mathrm{RR} 03$ with $\mathrm{CO}_{2}$ and without $\mathrm{CO}_{2}$-modified CFTRI RRAC I medium at different intervals in $10.0 \mathrm{~m}^{2}$ open raceway pond. (d) Total lipid content of $A$. coffeaeformis RR03 with $\mathrm{CO}_{2}$ and without $\mathrm{CO}_{2}$-modified CFTRI-RRAC I medium at different intervals $10.0 \mathrm{~m}^{2}$ open raceway pond.

The $1.0 \mathrm{~m}^{2}$ open raceway ponds contained $135 \mathrm{~L}$ of the modified CFTRI - RRAC I medium and F/2 medium (control) separately, and were inoculated with $15 \mathrm{~L}$ of optimally grown culture of A. coffeaeformis RR03, which revealed the following observations, as shown in Figure $3 a, b$. The $10.0 \mathrm{~m}^{2}$ raceway pond, which contained $1350 \mathrm{~L}$ of modified CFRTRI-RRAC I medium inoculated with optimally grown $150 \mathrm{~L}$ of $A$. coffeaeformis $\mathrm{RR} 03$ with $\mathrm{CO}_{2}$ supplementation, revealed the following observations, 
as shown in Figure 3c-f. The initial biomass of $0.12 \mathrm{~g} \mathrm{~L}^{-1}$ was gradually increased up to $0.78 \mathrm{~g} \mathrm{~L}^{-1}$ on 12th day, and it further increased to $1.5 \pm 0.10 \mathrm{~g} \mathrm{~L}^{-1}$ on 21 st day. The above biomass productivity was more than $50 \%$ of that of control (without $\mathrm{CO}_{2}$ supplementation). The alga cultivated in the pond supplemented with $\mathrm{CO}_{2}$ had a maximum cell number of $5.2 \times 10^{6}$ cell $/ \mathrm{mL}$ on 21 st day, as shown in Figure $2 \mathrm{a}, \mathrm{b}$. The alga showed the biomass productivity $0.071 \mathrm{~g} \mathrm{~L}^{-1} \mathrm{~d}^{-1}$, and volumetric and areal productivity of $0.065 \mathrm{~g} \mathrm{~L}^{-1} \mathrm{~d}^{-1}$ and $9.75 \mathrm{~g} \mathrm{~m}^{2} \mathrm{~d}^{-1}$, respectively.
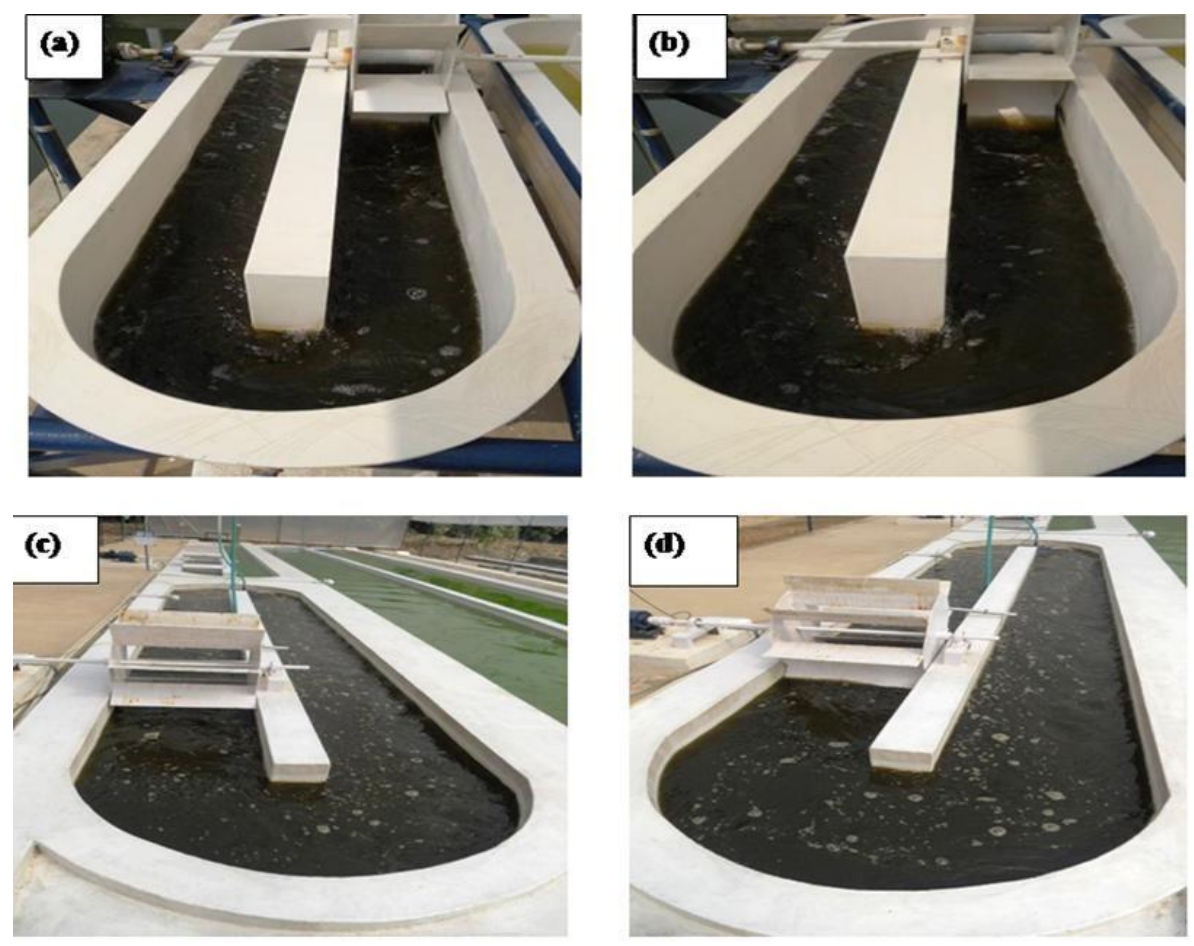

Figure 3. (a) Growth for F/2 medium. (b) Modified CFTRI-RRACI medium. (c,d) Different days of growth for modified CFTRI-RRAC-I medium in outdoor cultivation.

The culture without $\mathrm{CO}_{2}$ supplementation (control) showed a biomass productivity of $0.046 \mathrm{~g} \mathrm{~L} \mathrm{~L}^{-1} \mathrm{~d}^{-1}$ and a volumetric and areal productivity of biomass of $0.028 \mathrm{~g} \mathrm{~L}^{-1} \mathrm{~d}^{-1}$ and $4.2 \mathrm{~g} \mathrm{~L}^{-1} \mathrm{~m}^{2} \mathrm{~d}^{-1}$, correspondingly. In the $\mathrm{CO}_{2}$-supplemented pond, the $\mathrm{pH}$ of the algal culture was maintained between 8.0 and 8.5 , whereas in the pond without $\mathrm{CO}_{2}$ supplementation, the initial $\mathrm{pH}$ of 8.12 was raised to 9.18 on 9 th day and 9.85 on 21st day. At the end of study period, 2.250 and $1.395 \mathrm{~kg}$ of dry biomass were harvested in the ponds supplemented with $\mathrm{CO}_{2}$ and without $\mathrm{CO}_{2}$ supplementation, respectively (Figure 3g,h), and as shown in Table 1.

\subsubsection{Electro-Clarification}

A volume of $1500 \mathrm{~L}$ (per batch) withdrawn from the experimental ponds had a biomass concentration from 0.05 to $0.15 \%$ dry wt. The culture was treated for $\sim 3.5$ to $4.0 \mathrm{~h}$ with a flow rate of $600 \mathrm{~L} \mathrm{~h}^{-1}$ at the voltage $(\mathrm{V})$ and Ampere (A) from $1.8 \mathrm{~V}$ and $111 \mathrm{~A}$, and gave a biomass concentration of up to 1.1 to $2.4 \%$. The culture was then pumped to the blending tank and treated with $1 \mathrm{ppm}$ of polyelectrolyte (automated dosing pump). The polyelectrolyte-treated culture was overflowed into a $250 \mathrm{~L}$ clarifier, in which the algal flocs settled at the bottom of the clarifier, as shown in Figure 4a. The supernatant was overflowed through the outlet. The biomass recovery efficiency was calculated before and after addition of polyelectrolyte addition up to 79.13 to $94.54 \%$, and 91.62 to $99.57 \%$, respectively. 

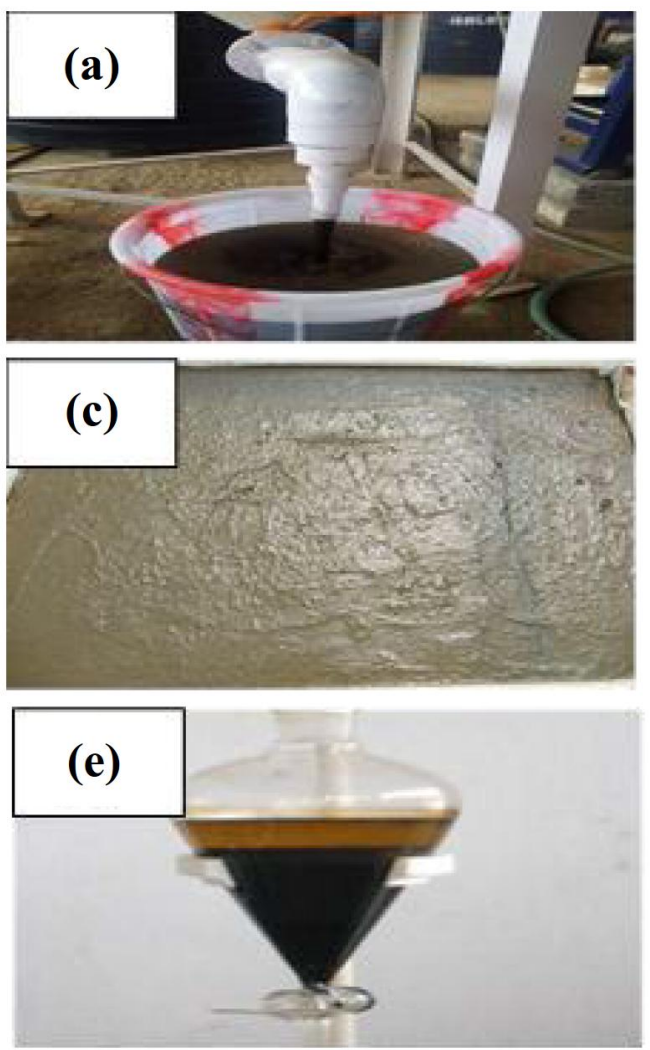
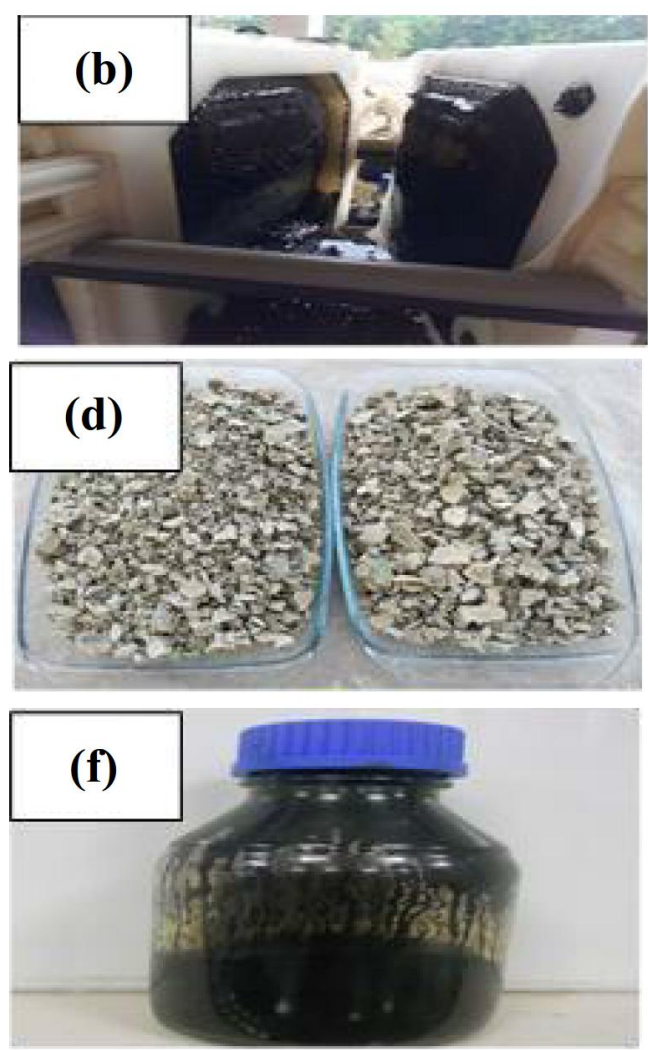

Figure 4. (a) Culture collection of clarifier. (b) Filter press. (c) Fresh biomass under sun dried. (d) Dry biomass. (e) Separated for bio-crude. (f) Bio-crude oil.

\subsubsection{Dewatering of Biomass}

Pressure filtration system was used to dewater from the algal slurry, which comprised a filter press. The algal slurry obtained through electro clarification (1.1 to $2.3 \%$ ) was pumped into filter press with a flow rate of $10 \mathrm{~L}$ per min, as shown in Figure $4 \mathrm{~b}$. Biomass recovery efficiency in this process was $99.5 \%$. Solid percentage ranged from 14.0 to $25.0 \%$. The harvested biomass after pressure filtration was dried under solar radiation for further study, as shown in Figure $4 \mathrm{c}, \mathrm{d}$.

\subsection{Hydro Thermochemical Liquefaction Process (HTL)}

2.4.1. Effect of Different Temperatures, Durations, and Pressures on Biocrude Yield of A. coffeaeformis RR03

The algal biomass of $80 \mathrm{~g}$ added with $400 \mathrm{~mL}$ of distilled water $(1: 5 w / v)$ at different conditions revealed that increasing temperatures, durations, and pressures enhanced the biocrude yield of A. coffeaeformis RR03 (Figure 4e,f). A maximum yield of 39.40\%/ash free biomass was achieved at $350{ }^{\circ} \mathrm{C}$, for $15 \mathrm{~min}$ at $171.1 \mathrm{psi}$ (Table 2).

Table 2. Effect of different temperatures, time durations, and pressures on bio-crude yield of $A$. coffeaeformis RR03 biomass obtained from $10.0 \mathrm{~m}^{2}$ open raceway pond without $\mathrm{CO}_{2}$ supplementation.

\begin{tabular}{ccccccc}
\hline $\begin{array}{c}\text { Dry } \\
\text { Biomass (g) }\end{array}$ & $\begin{array}{c}\text { Ash Free } \\
\text { Biomass (g) }\end{array}$ & $\begin{array}{c}\text { Distilled } \\
\text { Water }(\mathbf{m L})\end{array}$ & Temp. $\left({ }^{\circ} \mathbf{C}\right)$ & Duration (min) & Pressure (psi) & $\begin{array}{c}\text { Biocrude Yield/Ash } \\
\text { Free Biomass (\%) }\end{array}$ \\
\hline 80 & 30.96 & 400 & 280 & 10 & 70.6 & 29.39 \\
80 & 30.96 & 400 & 300 & 15 & 14.5 & 33.26 \\
80 & 30.96 & 400 & 330 & 10 & 171.1 & 30.36 \\
80 & 30.96 & 400 & 350 & 15 & 39.40 \\
\hline
\end{tabular}




\subsubsection{Elemental Analysis and C:N Ratio of Dry Biomass}

An attempt was made for the analysis of $\mathrm{C}, \mathrm{H}, \mathrm{N}, \mathrm{S}, \mathrm{O}$, and $\mathrm{C}: \mathrm{N}$ ratio of dry biomass of A. coffeaeformis RR03. In this study, A. coffeaeformis RR03 biomass obtained in the open raceway ponds, the diatom grown in F/2 medium, and modified CFTRI-RRAC I medium had maximum energy values of 3.48 and 4.72 Mega Joules (MJ). Similarly, the levels of Carbon and Hydrogen were maximums of $16.36,14.86 \%$ and $3.28,3.03 \%$, respectively (Table 3 ).

Table 3. Percentage of $\mathrm{C}, \mathrm{H}, \mathrm{N}, \mathrm{S}, \mathrm{O}$, and $\mathrm{C} / \mathrm{N}$ ratio of dry biomass of A. coffeaeformis RR03 under different conditions.

\begin{tabular}{cccccccc}
\hline Experimental Condition & $\mathbf{C}$ & $\mathbf{H}$ & $\mathbf{N}$ & $\mathbf{S}$ & $\mathbf{O}$ & C/N Ratio & Energy Value (Mega Joules) \\
\hline $\begin{array}{c}\text { A. coffeaeformis RR03 in } \\
\text { F/2 medium } 1.0 \mathrm{~m}^{2} \text { pond }\end{array}$ & 16.36 & 3.28 & 1.99 & 1.05 & 77.32 & 8.22 & 3.48 \\
\hline $\begin{array}{c}\text { A. coffeaeformis RR03 in } \\
\text { modified CFTRI-RRAC I } \\
\text { medium in } 1.0 \mathrm{~m}^{2} \text { pond }\end{array}$ & 14.86 & 3.03 & 1.78 & 0.95 & 79.38 & 8.35 & 4.72 \\
\hline
\end{tabular}

\subsubsection{Elemental Analysis and C:N Ratio of Biocrude from Diatoms at Different Conditions}

The bio crude samples required different element analyses such as (Corban, Hydrogen, Nitrogen Sulfer, and Oxygen) C, H, N, S, O, and C:N ratio. Energy values as Mega Joules (MJ) were also calculated and presented. Biocrude of $A$. coffeaeformis RR03 obtained from F/2 medium and modified CFTRI-RRAC I medium showed the energy values of 31.70 and 36.19 Mega Joules, respectively (Table 4).

Table 4. Percentage of $\mathrm{C}, \mathrm{H}, \mathrm{N}, \mathrm{S}$, and $\mathrm{O}$ of bio crude of $A$. coffeaeformis RR03 under different conditions.

\begin{tabular}{cccccccc}
\hline Experimental Condition & C & H & N & S & O & C/N Ratio & Energy (Mega Joules) \\
\hline $\begin{array}{c}\text { A. coffeaeformis RR03 in F/2 medium } 1.0 \mathrm{~m}^{2} \\
\text { open raceway pond condition: } 350^{\circ} \mathrm{C} \text { for } \\
15 \text { min at } 171.1 \mathrm{psi}\end{array}$ & 75.87 & 8.93 & 2.39 & 0.30 & 12.51 & 31.74 & 31.70 \\
\hline $\begin{array}{c}\text { A. coffeaeformis RR03 grown in modified } \\
\text { CFTRI-RRAC I medium in } 1.0 \mathrm{~m}^{2} \text { raceway } \\
\text { pond: } 3500^{\circ} \mathrm{C} \text { for } 15 \text { min at } 171.1 \mathrm{psi}\end{array}$ & 77.36 & 6.82 & 4.36 & 1.53 & 9.93 & 17.74 & 36.19 \\
\hline
\end{tabular}

\subsubsection{Fatty Acid Contents}

The fatty acid composition of FAME obtained from the chloroform extracted dry biomass was analysed under GC-MS. It contained a maximum of $47.72 \% 16$. octadecanoic acid methyl ester (10:12), followed by pentadecanoic acid, 13 methyl esters $(9: 24)$ of $19.58 \%$, and minimum of $7.95 \%$ n-Hexadecanoic acid methyl esters (14:52) (Figure $4 \mathrm{~g}$ ) of the organism suitable for biofuel production.

\section{Discussion}

The present investigation has demonstrated the cultivation of marine diatom on a large scale in artificial seawater medium with minimum expenditure. Improved algal growth was ultimately obtained in the laboratory under optimal conditions. The results of this study show that a novel diatom of A. coffeaeformis RR03 could be a suitable candidate for biocrude production: it could meet the future demand of energy, because it contains high amount of biomass.

The mass culture of marine algae is dependent on natural seawater, both in open tanks and in closed controlled systems [12]. Many algae species have high lipid content and they grow on non-arable land using alternative seawater [13]. In the present study, mass cultivation trials of A. coffeaeformis RR03 in the modified CFTRI-RRAC I medium were made; the diatom that was cultivated in $1.0 \mathrm{~m}^{2}$ open raceway pond without $\mathrm{CO}_{2}$ supplementation showed that the alga attained a maximum of $0.81 \mathrm{~g} \mathrm{~L}^{-1}$ with $2.51 \times 10^{6}$ cells $/ \mathrm{mL}$ on the 15th day. A modified CFTRI-RRAC I medium optimized in the present attempt is supported by the organism for a maximum accumulation of $149 \mathrm{mg} \mathrm{L}^{-1}$ of lipid content on 
15th day. It was more than the alga grown in $\mathrm{F} / 2$ medium (control). The alga A. coffeaeformis RR03 showed maximum lipid productivity of $9.93 \mathrm{mg} \mathrm{L}^{-1} \mathrm{~d}^{-1}$ in the modified CFTRI-RRAC I medium. The concentration of chlorophyll- $a$ maximum of $6.09 \mathrm{mg} \mathrm{L}^{-1}$ on 15th day when grown in modified CFTRI-RRAC I medium was higher than in the control (F/2 medium). James and Al-Khars [14] have also found similar high yield of Nannochloropsis sp. and Chlorella in a lucent vertical air-lift photobioreactor and obtained maximum productivities of 26 to $20 \mathrm{~g} \mathrm{~m}^{2} \mathrm{~d}^{-1}$ on a dry weight basis.

The mass cultivation of $A$. coffeaeformis RR03 in modified CFRTRI-RRAC I medium in $10.0 \mathrm{~m}^{2}$ open raceway pond supplemented with $\mathrm{CO}_{2}$ and the $\mathrm{pH}$ was maintained in a range of 8.0-8.5, whereas the culture without $\mathrm{CO}_{2}$ supplementation of the $\mathrm{pH}$ was raised up to 9.16. The reduction of $\mathrm{pH}$ in $\mathrm{CO}_{2}$-supplemented culture could be due to the dissolution of $\mathrm{CO}_{2}$ into carbonic acid. $\mathrm{CO}_{2}$ supplementation enhanced biomass productivity when compared to that of control (without $\mathrm{CO}_{2}$ supplementation), thus indicating the possible utilization of $\mathrm{CO}_{2}$ as carbon source for increase biomass of $1.5 \mathrm{~g} \mathrm{~L}^{-1}$ on 21st day. However, $\mathrm{CO}_{2}$ supplementation decreased accumulation of lipid content of the alga.

Carbon dioxide supplementation in modified CFRTRI-RRAC I medium supported the diatom for maximum accumulation of Chlorophyll- $a$ content of $13.18 \mathrm{mg} \mathrm{L}^{-1}$ on $21 \mathrm{st}$ day. The growth rates, biomass, and lipid content of microalgae are manifestly enhanced by freshening with essential for levels of $\mathrm{CO}_{2}$ [15]. Addition of extra $\mathrm{CO}_{2}$ can increase growth rates, which has been demonstrated by various experiments with large amounts of microalgae cultivation in carbon sequestration. The dissolved $\mathrm{CO}_{2}$ can spontaneously change to carbonic acid to form bicarbonate, and carbonate makes $\mathrm{CO}_{2}$ dissolve in the medium. However, it lowers the $\mathrm{pH}$, which reduces growth for most species. The $\mathrm{pH}$ of medium under $\mathrm{CO}_{2}$ supplementation was not allowed to be lower than $\mathrm{pH}$ 8.0, but was maintained between 8.0 and 8.5 , which supported the organism for achieving maximum biomass productivity.

Low broth of algae generally accumulate heavily, whereas the cells normally carry negative charge and contain excess of algogenic organic matters to their immovability in a circulated condition [16]. The harvesting technique charges the properties of microalgae such as algal density, size, and value of the desired products [17]. Bioflocculation and electroclarification were followed by harvest diatoms biomass. Flocculation is one of the chemical technologies in the microalgae harvesting. The chamber using a filter press in the absorption of 245 could be attained for the large microalga C. proboscideum to produce a cake with $27 \%$ solids [18]. In the present attempt, diatom slurry samples were successfully obtained through pressure filtration system. The algal slurry was then exposed to solar radiation for a day and stored under room temperature. The ventilation promotes dewatering process that was also categorized by solid content and recovery time. In the all-purpose, the solid content after the harvested biomass can easily exceed $90 \%$, while the recovery rate can reach $95 \%$.

Harvested algae contained $97-99 \%$ of water. The removals of excessive water are necessary for the long-term storage of algae feedstock and are also required for many downstream processes. To maintain microalgae from long-lasting microbial growth, the moisture level of harvested algae was kept below 7\%. Drying is an energy-intensive process and it describes total production costs of up to $30 \%$. Natural drying (solar and wind) is the most economical method; however, it is weather-dependent and requires large space [19].

\section{Materials and Methods}

\subsection{Sample Collection and Isolation of Microalgae}

Seawater samples were collected from different coastal regions of Tamil Nadu, India, during August and September 2009. Different seawater samples were collected along the coast of Kanyakumari; Tuticorin; Rameswaram; and Chennai, Tamil Nadu, India using phytoplankton net of $25 \mu \mathrm{m}$. In addition, saltpan samples were collected from Kovelong near Chennai, India. The samples were brought to the laboratory and inoculated in the F/2 medium [20]. Fast growing microalgae 
strains were isolated and purified using serial dilution technique with spread plate method on $2 \% \mathrm{~F} / 2$ agar medium. The isolated microalgae were cultured in the basal medium.

\subsection{Identification of Microalgal Isolates}

The algal isolates were identified based on their morphological characteristics observed under compound microscope using standard monographs. Bacillariophyceae members (Diatoms) were identified based on the description given by Al-Kandari et al. [21]. All the isolated diatom samples were treated with concentrated Nitric acid (HNO3) overnight to remove organic material from the cell. The samples were centrifuged at $1000 \mathrm{~g}$; the pellet was washed with distilled water several times to remove the nitric acid, and then the samples were used for identification. All the isolated microalgae were made into unialgal cultures and maintained in the basal medium under laboratory conditions at $22 \pm 2{ }^{\circ} \mathrm{C}$ in a thermostatically controlled room, illuminated with cool white fluorescent lamps at an intensity of $30 \mu \mathrm{Em}^{-2} \mathrm{~s}^{-1}$, with a 12:12 h of light: dark regime.

\subsection{Mass Cultivation of Amphora Coffeaeformis RR03 in an Open Raceway Pond}

The diatoms of $A$. coffeaeformis RR03 were grown in the modified CFTRI-RRAC I medium in an open raceway pond. The modified CFTRI-RRAC I medium was prepared by mixing urea $(200 \mathrm{mg} / \mathrm{L})$, super phosphate $(40 \mathrm{mg} / \mathrm{L})$, potash $(100 \mathrm{mg} / \mathrm{L})$, sodium silicate $(35 \mathrm{mg} / \mathrm{L})$, magnesium sulphate ( $250 \mathrm{mg} / \mathrm{L})$, sodium bicarbonate $(250 \mathrm{mg} / \mathrm{L})$, ferric chloride $(10 \mathrm{mg} / \mathrm{L})$, and salinity (30 ppt) in a litre of artificial seawater and adjusted $\mathrm{pH}$ 8.0. The culture was grown in $150 \mathrm{~L}$ and $1500 \mathrm{~L}$ open raceway pond. The $30 \mathrm{~mL}$ of optimally grown algal samples was inoculated in $270 \mathrm{~mL}$ of the basal medium of 500 Erlenmeyer flask and kept in an outdoor condition for a period of 21 days. Every 3 days, the number of diatom cells was recorded and expressed as $10^{-6}$ cells/mL [22], chlorophyll-a, [23], and dry biomass [24]; total lipid [25] were also recorded.

\subsection{Details of Raceway Ponds}

The raceway ponds of $1.0 \mathrm{~m}^{2}$ with $150 \mathrm{~L}$ capacity and $10.0 \mathrm{~m}^{2}$ of $1500 \mathrm{~L}$ at the premises of the Aban Infrastructure Pvt Ltd., Biotechnology Division, Chennai, India were used to conduct the field trail. The details of the raceway ponds are summarised in the Table 1 . The concrete pond raceway floors are coated with FRP material (fibre-reinforced polymer) and RP (reinforced polymer). The raceway ponds were provided with a paddle wheel system for aeration at $10 \mathrm{rpm}$. During the experimental period, the evaporation loss of the medium was compensated with bore well water. An outlet was also provided in each pond at the bottom to enable cleaning whenever required. The raceway ponds are protected from dust, etc., on the top with transparent polythene sheet. The raceway ponds are also connected with carbonation column. The raceway floors are coated with FRP material and designed as length inner 2.22, 7.00; width inner 0.50, 1.50; depth (m) 0.26, 0.26; partition wall length 1.79, 5.55; partition wall width $0.20,0.22$, bottom area $0.76,9.30$; and the total working volume of $200 \mathrm{~L}$ and $2000 \mathrm{~L}$

\subsection{Sterilization of Medium}

The $1.0 \mathrm{~m}^{2}$ and $10.0 \mathrm{~m}^{2}$ raceway ponds were added with $135 \mathrm{~L}$ and $1350 \mathrm{~L}$ medium, respectively, and added about $10 \mathrm{ppm}$ of sodium hypochlorite and aerated overnight using the paddle wheel at $10 \mathrm{rpm}$. Subsequently, $0.285 \mathrm{ppm}$ of sodium thiosulphate was added to neutralize the medium. The level of free chlorine was checked using Hach spectrophotometer (DR 2700, Hach, Düsseldorf, Germany), and if there was any chlorine, it was neutralized by adding sufficient amount of sodium thiosulphate until nil chlorine in the medium was recorded.

\subsection{Determination of Chlorine}

The samples were filtered through $0.2 \mu \mathrm{m}$ membrane, and the filtrates were collected for the analysis. To $10 \mathrm{~mL}$ of the sample, one DPD-free chlorine powder pillow was added and vortexed. 
Development of the colour pink indicated the presence of chlorine and colourlessness indicated absence of chlorine.

\subsection{Preparation of Inoculum in $1.0 \mathrm{~m}^{2}$ and $10.0 \mathrm{~m}^{2}$ Raceway Pond}

Fifteen litres of optimally grown alga culture were obtained from the laboratory condition and transferred to the $1.0 \mathrm{~m}^{2}$ open raceway pond containing $135 \mathrm{~L}$ medium. The inoculum was raised in the following order: optimally grown $15 \mathrm{~L}$ of diatom culture was collected under laboratory conditions and transferred into the $1.0-\mathrm{m}^{2}$ raceway pond containing $135 \mathrm{~L}$ medium and maintained for 10 days. Then, the culture $(150 \mathrm{~L})$ was transferred to $10.0 \mathrm{~m}^{2}$ raceway pond contained $1350 \mathrm{~L}$ of medium. This medium was used for mass cultivation outdoor condition.

\subsection{Harvesting of Biomass}

The raceway ponds $\left(1.0 \mathrm{~m}^{-2}\right)$ containing $135 \mathrm{~L}$ medium were inoculated with $15 \mathrm{~L}$ of optimally grown culture of $A$. coffeaeformis RR03. This experiment was conducted for a period of 21 days during the month of June-2013. At the end of the study period, the diatom biomass were harvested using electroclarification process and filter press technique. The algal culture from the experimental pond was pumped into the collection/storage tank and subjected to electroclarification process. The culture was circulated at a flow rate of $\sim 600 \mathrm{~L} \mathrm{~h}^{-1}$ via the reaction chamber. The volume of the chamber was of $50 \mathrm{~L}$ with one stainless steel electrode placed at the centre $(0.5$ sq.m). The retention time inside the reaction chamber was $25 \mathrm{~min}$. The reaction was carried out at Voltages 1.8 and 111 Amperes. The culture in the reaction chamber was continuously agitated at $100 \mathrm{rpm}$ and added $1.0 \mathrm{ppm}$ of polyelectrolyte using a dosing pump. The polyelectrolyte-treated culture was then overflow into a $250 \mathrm{~L}$ clarifier, in which the algal slurry settled at the bottom of the clarifier was taken for further processing. The supernatant was continuously overflowed through the outlet placed just $15.0 \mathrm{~cm}$ from the top of the clarifier. Subsequently, dewatering of biomass was made using filter press. The pressure filtration system comprised a filter press. It contained 15 plates and 15 frames, over which plankton material of $5 \mu \mathrm{m}$ was placed. The plates and frames were tightened using a manual hydraulic closing system at $250 \mathrm{~kg} / \mathrm{cm}^{2}$ pressure. There were two inlets and two outlets (lower and upper) for pumping of algal slurry and collection of supernatant, respectively. There were also individual outlets in each of the frames for cross-checking the filtration efficiency of the filter cloth material inside the frame. A suitable provision was made for recirculation of the excess slurry from the inlet by means of a bypass valve. After filtration of the slurry, air compressor was used to dry the slurry inside the frames, which also aided in the formation of wet algal cakes. Then, the frames were separated; the algal cakes were scraped off manually and made into dry algal flakes by drying under sun light for 3 days.

\subsection{Hydro Thermochemical Liquefaction (HTL)}

The biomass of diatoms collected in this study was subjected for the reaction of hydro thermochemical liquefaction. Hydro thermochemical liquefaction process was conducted using $1.1 \mathrm{~L}$ capacity Inconel high-pressure reactor (reliance, floor stand model). After adding the algal slurry to the reaction vessel, the reactor was tightly closed and conducted the experiment at different temperatures, pressures, and durations. An impeller type of agitation device at $250 \mathrm{rpm}$ stirred the reaction mixture to ensure homogeneous reactions.

At the end of reaction, the samples were cooled to room temperature and collected in a separating funnel, and the biocrude was allowed to settle. The solid phase at the bottom of the separating funnel was collected and extracted three times washed with water in dichloromethane $(1: 1 \mathrm{v} / \mathrm{v})$ and recovered hydrocarbons. The dichloromethane fractions were pooled and evaporated using a distillation setup at $39{ }^{\circ} \mathrm{C}$ to obtain biocrude. The yield of biocrude fraction was expressed as percentage and estimated for its elemental composition such as $\mathrm{C}, \mathrm{H}, \mathrm{N}, \mathrm{O}$, and $\mathrm{S}$ using Elemental Analyzer (Vario EL III, Elementar India Pvt. Ltd., Gurugram-122002, Haryana, India). The Gross 
Calorific Value/Higher Heating Value (HHV) was calculated according to Dulong's formula [26]. $\mathrm{HHV}(\mathrm{MJ} / \mathrm{kg})=0.338 \mathrm{C}+1.428(\mathrm{H} \mathrm{O} / 8)+0.095$.

\subsection{Effect of Different Temperatures, Durations, and Pressure on Biocrude Yield of A. coffeaeformis RR03}

The biomass of $A$. coffeaeformis RR03 obtained from $10.0 \mathrm{~m}^{2}$ openraceway pond (without $\mathrm{CO}_{2}$ supplementation being taken, $80 \mathrm{~g}$ of dry biomass was added with $400 \mathrm{~mL}$ distilled water $(1: 5 \mathrm{w} / \mathrm{v})$ and kept at different temperatures such as, $280,300,330$, and $350^{\circ} \mathrm{C}$; duration of each $15 \mathrm{~min}$ : and pressures such as, 70.6, 97.5, 141.1, and $171.1 \mathrm{psi}$, respectively, and subjected to hydro thermochemical liquefaction process. The values of biocrude were expressed in terms of percentage /ash free biomass).

\subsection{Direct Biomass Acid Transesterification}

Direct transesterification was carried out as per the method described by Johnson and Wen [27]. Dry algal biomass of $100 \mathrm{~g}$ was added with $3.4 \mathrm{~mL} \mathrm{~g}^{-1}$ of methanol and $0.6 \mathrm{~mL} \mathrm{~g}^{-1}$ of sulphuric acid. To this sample, $4.0 \mathrm{~mL} \mathrm{~g}^{-1}$ of each methanol, chloroform: methanol (2:1 $\left.v / v\right)$, followed by hexane and petroleum ether, was added. The reaction mixture was kept at $90{ }^{\circ} \mathrm{C}$ in a water bath for $40 \mathrm{~min}$, and it was thoroughly mixed intermittently during heating. Then, the mixture was allowed to cool at room temperature, $2.0 \mathrm{~mL} \mathrm{~g}^{-1}$ distilled water was added and mixed for $45 \mathrm{~s}$, and the samples were allowed for separation of different phase. The biodiesel (FAME) was separated in the solvent layer, which was collected and transferred to a pre weighed glass vial. The solvent was evaporated using liquid $\mathrm{N}_{2}$, and the quantified amount of biodiesel gravimetrically and its fatty acid composition were analysed by GC-MS.

\section{Conclusions}

The results showed that a newly identified marine diatom A. coffeaeformis RR03 was highly produced on the 21st day with $\mathrm{CO}_{2}$ supply. The bio-crude oil production in this alga was about 36.19 megajoule. The most favourable concentration of $\mathrm{C} / \mathrm{N}$ ratios and energy was noticed when the algae were nurtured under our own culture medium of CFTRI-RRAC I. GC-MS analysis revealed that A. coffeaeformis RR03 contained $47.72 \%$ 16-octadecanoic acid methyl ester and $19.58 \%$ pentadecanoic acid, 13-methyl-, and methyl ester, which might be suitable for the production of good-quality biofuel. The results of this study may suggest that the diatom A. coffeaeformis RR03 could be a suitable candidate for succeeding biofuel.

Author Contributions: M.G.R. and R.R. conceived and designed the experiments. M.G.R. performed the experiments, S.N. and M.M analyzed the data, A.B.B. and C.K. contributed reagents/materials/analysis tools, and R.R. and T.J wrote the paper. J.-R.S. and J.-Y.L. contributed interpretations and assistance to the manuscript. All authors were involved in editing the manuscript.

Acknowledgments: We are extremely thankful to the Director, CAS in Botany for providing the laboratory facility and the Aban Infrastructure for extending the necessary facility to carry out the research work. M.G.R. is thankful to the UGC (GCCO/A2/UGC/RR/CASB/MER-Fellow/2009/1481), New Delhi for financial support. We also acknowledge the Ministry of Science and Technology of Taiwan (MOST103-2320-B-038-017, MOST104-2622-B-038-003, MOST 104-2320-B-038-045-MY2).

Conflicts of Interest: There is no conflict of interest.

\section{References}

1. Zeng, X.; Danquah, M.K.; Chen, X.D.; Lu, Y. Microalgae bioengineering: From $\mathrm{CO}_{2}$ fixation to biofuel production. Renew. Sustain. Energy Rev. 2011, 15, 3252-3260. [CrossRef]

2. Hildebrand, M.; Davis, A.K.; Smith, S.R.; Traller, J.C.; Abbriano, R. The place of diatoms in the biofuels industry. Biofuels 2012, 3, 221-240. [CrossRef]

3. De Bhowmick, G.; Subramanian, G.; Mishra, S.; Sen, R. Raceway pond cultivation of a marine microalga of indian origin for biomass and lipid production: A case study. Algal Res. 2014, 6, 201-209. [CrossRef] 
4. Lam, M.K.; Lee, K.T.; Mohamed, A.R. Current status and challenges on microalgae-based carbon capture. Int. J. Greenh. Gas Control 2012, 10, 456-469. [CrossRef]

5. Kumar, V.; Karela, R.P.; Korstad, J.; Kumar, S.; Srivastava, R.; Bauddh, K. Ecological, Economical and Life Cycle Assessment of Algae and Its Biofuel. In Algal Biofuels; Springer: Cham, Switzerland, 2017; pp. 451-466.

6. Brennan, L.; Owende, P. Biofuels from microalgae-A review of technologies for production, processing, and extractions of biofuels and co-products. Renew. Sustain. Energy Rev. 2010, 14, 557-577. [CrossRef]

7. Sakthivel, R. Microalgae lipid research, past, present: A critical review for biodiesel production, in the future. J. Exp. Sci. 2011, 2, 10.

8. Sforza, E.; Bertucco, A.; Morosinotto, T.; Giacometti, G. Vegetal oil from microalgae: Species selection and optimization of growth parameters. Chem. Eng. Trans. 2010, 20, 199-204.

9. Alcaine, A.A. Biodiesel from microalgae. Universitat Politècnica de Catalunya. Escola Universitàriad'Enginyeria Tècnica Industrial d'Igualada; ET Industrial, especialitat en Química Industrial: Barcelona, Spain, 2010.

10. Rawat, I.; Kumar, R.R.; Mutanda, T.; Bux, F. Biodiesel from microalgae: A critical evaluation from laboratory to large scale production. Appl. Energy 2013, 103, 444-467. [CrossRef]

11. Kwietniewska, E.; Tys, J. Process characteristics, inhibition factors and methane yields of anaerobic digestion process, with particular focus on microalgal biomass fermentation. Renew. Sustain. Energy Rev. 2014, 34, 491-500. [CrossRef]

12. Ansell, A.; Raymont, J.; Lander, K.; Crowley, E.; Shackley, P. Studies on the mass culture of Phaeodactylum. Ii. The growth of Phaeodactylum and other species in outdoor tanks. Limnol. Oceanogr. 1963, 8, 184-206. [CrossRef]

13. Borowitzka, M.A. Commercial production of microalgae: Ponds, tanks, tubes and fermenters. J. Biotechnol. 1999, 70, 313-321. [CrossRef]

14. James, C.M.; Al-Khars, A. An intensive continuous culture system using tubular photobioreactors for producing microalgae. Aquaculture 1990, 87, 381-393. [CrossRef]

15. Riebesell, U. Effects of $\mathrm{CO}_{2}$ enrichment on marine phytoplankton. J. Oceanogr. 2004, 60, 719-729. [CrossRef]

16. Uduman, N.; Qi, Y.; Danquah, M.K.; Forde, G.M.; Hoadley, A. Dewatering of microalgal cultures: A major bottleneck to algae-based fuels. J. Renew. Sustain. Energy 2010, 2, 012701. [CrossRef]

17. Danquah, M.K.; Ang, L.; Uduman, N.; Moheimani, N.; Forde, G.M. Dewatering of microalgal culture for biodiesel production: Exploring polymer flocculation and tangential flow filtration. J. Chem. Technol. Biotechnol. 2009, 84, 1078-1083. [CrossRef]

18. Zhang, F.; Cheng, L.; Xu, X.; Zhang, L.; Chen, H. Technologies of microalgal harvesting and lipid extraction. Prog. Chem. 2012, 24, 2062-2072.

19. Becker, E.W. Microalgae: Biotechnology and Microbiology; Cambridge University Press: Cambridge, UK, 1994.

20. Guillard, R.R.; Ryther, J.H. Studies of marine planktonic diatoms: I. Cyclotella nana hustedt, and Detonulaconfervacea (cleve) gran. Can. J. Microbiol. 1962, 8, 229-239. [CrossRef] [PubMed]

21. Al-Kandari, M.; Al-Yamani, F.; Al-Rifaie, K. Marine phytoplankton atlas of Kuwait waters. In Marine Phytoplankton Atlas; Kuwait Institute for Scientific Research: Safat, Kuwait, 2009; ISBN 99906-99941.

22. Sournia, A. Phytoplankton Manual; UNESCO: Paris, French, 2013.

23. Jeffrey, S.T.; Humphrey, G. New spectrophotometric equations for determining chlorophylls a, b, c1 and c2 in higher plants, algae and natural phytoplankton. Biochem. Physiol. Pflanzen 1975, 167, 191-194. [CrossRef]

24. Moheimani, N.R. The Culture of Coccolithophorid Algae for Carbon Dioxide Bioremediation. Ph.D. Thesis, Murdoch University, Perth, Australia, 2005.

25. Folch, J.; Lees, M.; Sloane Stanley, G. A simple method for the isolation and purification of total lipids from animal tissues. J. Biol. Chem. 1957, 226, 497-509. [PubMed]

26. Li, Q.; Du, W.; Liu, D. Perspectives of microbial oils for biodiesel production. Appl. Microbiol. Biotechnol. 2008, 80, 749-756. [CrossRef] [PubMed]

27. Johnson, M.B.; Wen, Z. Production of biodiesel fuel from the microalga Schizochytrium limacinum by direct transesterification of algal biomass. Energy Fuels 2009, 23, 5179-5183. [CrossRef]

(C) 2018 by the authors. Licensee MDPI, Basel, Switzerland. This article is an open access article distributed under the terms and conditions of the Creative Commons Attribution (CC BY) license (http:/ / creativecommons.org/licenses/by/4.0/). 